\title{
Onde o físico encontra o humano: proposição de um programa de pesquisa multidimensional para uma geografia da música baseada em ruído
}

\author{
Nina Puglia Oliveira \\ Universidade de Brasília (UnB), Brasil. \\ Dante Flávio da Costa Reis Júnior \\ Universidade de Brasília (UnB), Brasil.
}

Recibido: 24 de abril de 2020. Aceptado: 22 de marzo de 2021.

\begin{abstract}
Resumo
Neste artigo, propomos um programa de pesquisa que, definindo como objeto a relação entre "paisagem sonora" e "ruído", sugere que o campo da Geografia da Música pode estar melhor subsidiado pela incorporação simultânea de três perspectivas temáticas ou dimensões: ou "dimensões": a física, a orgânica e a cultural. Ampliando a perspectiva cultural fenomenológica, buscamos empreender uma proposta de análise multidimensional sobre o comportamento espacial das paisagens sonoras que influenciam na produção de música e, consequentemente, na formação de identidades musicais. Amparados pela geografia dos ruídos como um desdobramento da geografia sônica, acrescentam-se conceitos fundamentais de acústica, fisiologia da audição e neurociência. Espera-se, assim, consolidar uma proposta teórico-epistemológica que promova pontos de intersecção entre as geografias física e humana, e a compreensão da música enquanto linguagem e enquanto fenômeno humano a partir de um fenômeno natural.
\end{abstract}

PALAVRAS-CHAVE: PAISAGEM SONORA. SOM. RUÍDO. GEOGRAFIA SÔNICA. GEOGRAFIA DA MÚSICA.

\section{Where the physical meets the human: proposition of a multidimensional research program for a music geography based on noise}

\begin{abstract}
In this article, we propose a research program that, defining as subject matter the relationship between "soundscape" and "noise", suggests that the field of Music Geography may be better fed by the simultaneous incorporation of three thematic perspectives or "dimensions": physical, organic and cultural. Expanding the phenomenological cultural perspective, we seek to undertake a multidimensional analysis proposal on the spatial
\end{abstract}


Onde o físico encontra o humano: proposição...

Nina Puglia Oliveira, Dante Flávio da Costa ReIs JúNioR

behavior of soundscapes that influence music production and, consequently, in the formation of musical identities. Supported by the geography of noise as an unfolding field of sonic geography, fundamental concepts of acoustics, hearing physiology and neuroscience are added. Therefore, itis expected to consolidate a theoretical-epistemological proposal that promotes points of intersection between physical and human geographies, and the understanding of music as a language, and as a human phenomenon derived from a natural one.

KEYWORDS: SOUNDSCAPE. SOUND. NOISE. SONIC GEOGRAPHY. MUSIC GEOGRAPHY.

PALABRAS CLAVE: PAISAJE SONORO. SONIDO. RUIDO. GEOGRAFÍA SÓNICA. GEOGRAFÍA MUSICAL.

\section{Introdução}

Estamos habituados a sugerir que uma abordagem tipicamente "geográfica" é aquela que se caracteriza por uma concertação, em âmbito espacial, dos múltiplos aspectos de um dado fenômeno ou processo. E pode estar subjacente ao imaginário de muitos de nós a ideia subsequente de que, neste caso, é oportuno ter algum domínio destas várias perspectivas; a fim de que, justamente, uma abordagem integrada possa vir à tona. Por outro lado, é ingênuo pensarmos que cada uma delas detém uma inscrição epistemológica muito intrínseca - e a ponto de legitimar o entendimento (por fim, errôneo) de que seria suficiente um "encaixe" ou acomodação mútua dos aspectos para que cheguemos a uma dimensão "conectiva” (que é, por exemplo, uma paisagem). Em outras palavras, podemos nos surpreender com o fato de que os campos disciplinares que tratem de um ou outro aspecto do fenômeno (o "som" "om", digamos, que pode tanto receber um tratamento em mecânica ondulatória, quanto via fisiologia da audição, ou ainda em psicologia cognitiva), eles mesmos já o exploram sob um viés compósito; quer dizer, por considerarem a manifestação de outras interfaces simultâneas (que transcendem, pois, às fronteiras convencionais das ciências naturais, sociais), provam ser fontes de consulta incontornáveis.

Ademais, esse entendimento sobre a oportunidade em fazer confluírem saberes de várias ordens até um ponto comum é inclusive sancionado pela própria natureza da Geografia, Disciplina que, tradicionalmente, investe esforços em decifrar a manifestação espacial dos fenômenos ou, ao menos, representá-los interpretativamente em escala espacial.

Em A Natureza do Espaço, Milton Santos (2008:86, grifo nosso) pontua que "o espaço geográfico deve ser considerado como algo que participa igualmente da condição do social e do físico, um misto, um híbrido". Portanto, o espaço é resultado de um complexo conjunto de ações e objetos produzidos pelos seres humanos no decorrer da história e intermediado por algum modo de produção. Se o espaço é um híbrido entre o que a natureza nos oferece e o que fazemos com ela (e como o fazemos), estamos, em tese, autorizados a eleger o "som" como elemento de partida para uma investigação espacial sobre tudo aquilo que dele derive... como, por exemplo, a música.

Nesse sentido, compreender os processos de percepção dos sons e sua transformação em música, para além do viés fenomenológico da geografia cultural, é trazer uma nova perspectiva sobre como as sociedades humanas manipularam e transformaram um fenômeno natural em linguagem, ou seja, um fenômeno substancialmente humano. 
Onde o físico encontra o humano: proposição...

Nina Puglia Oliveira, Dante Flávio da Costa ReIs JúNioR

Assim sendo, a música revela-se resultante de uma das possíveis relações que os seres humanos estabelecem com o meio natural, o que, em Geografia, caracteriza formação e reprodução de espaço.

Entendemos que a partir da perspectiva de investigação científica de bases realista e empirista, atrelada à teoria espacial, seja possível traçar uma linha de raciocínio para analisar a formação de uma identidade musical, tendo a percepção da paisagem sonora como principal eixo norteador. Sendo o som e o ruído duas faces de um mesmo fenômeno natural, a maneira como os seres humanos percebem e decodificam os sons e ruídos, e os transformam em música, é um processo que envolve a correlação entre as dimensões física, fisiológica e cultural.

O caráter heterogêneo dos fenômenos/objetos que constituem os estudos de ordem geográfica é discutido por Reginald G. Golledge no texto Philosofical bases of behavioral research in geography. Golledge (2006) explana ali sobre como o/a geógrafo/a pode trabalhar com um olhar acerca do "comportamento espacial" (space behavior) de um fenômeno/objeto, considerando que esta seria, a priori, uma proposta de análise precisamente multidimensional. $\mathrm{O}$ autor esclarece que o comportamento espacial não tem relação com a vertente comportamental da psicologia de Skinner, mas desenvolve, apoiando-se em teóricos como Piaget, Lewin e Tolman, uma metodologia de pesquisa perceptiva-cognitiva. E destaca que o "geógrafo comportamental" (behavioral geographer) está interessado em "buscar as explicações de determinado processo", ou seja, produzir uma geografia com "ênfase no processo e não na forma" (Golledge, 2006:75). Sobreleva também que, sob esta perspectiva de análise, não é interessante ao/à geógrafo/a restringir-se aos estudos exclusivamente "geográficos”. É peremptório, então, recorrer à intersecção com outros campos de estudo científico; incluindo o das ciências naturais.

Os estudos geográficos nos quais o som é objeto de investigação estão agrupados sob o epíteto "geografia sônica" (sonic geography). Uma das ramificações é a geografia do ruído, alavancada, mormente, por Frédéric Roulier (1999). O artigo Sonic geographies: themes, concepts, and deaf spots, de Daniel Paiva (2018), traz um bom panorama de pesquisas em geografia sônica. Dentre elas, há trabalhos nos quais é feita a interface entre som e arte e, portanto, música., De acordo com o professor da Universidade de Lisboa, "um aspecto central em todas as geografias do som e das artes é a questão da mediação. O som na arte é entendido como um meio estético que ressoa e cria relações entre corpos, paisagens, animais, representações e objetos" (Paiva, 2018:3, tradução nossa). Ora, quando o compositor austríaco Arnold Schoenberg (1874-1951), considerado no ramo musical como o "pai" do Serialismo, ${ }^{1}$ coloca em seu tratado Harmonia ${ }^{2}$ que "nossa preocupação deve ser meditar continuamente sobre as misteriosas causas dos efeitos da arte (...) nada tendo por definitivo senão os fenômenos" (Schoenberg, 2001:43), fica evidente a necessidade de compreender a produção de música sob uma perspectiva multidimensional e na qual, então, inclusive os fatores de ordem espacial sejam considerados para uma compreensão integrada do processo de fazer música. Golledge (2006:77, tradução nossa) também argumenta que o/a geógrafo/a

1 Técnica de composição basilar da música atonal do início do século $X X$.

2 Publicado originalmente em 1911 (Harmonielehre). 
Onde o físico encontra o humano: proposição...

Nina Puglia Oliveira, Dante Flávio da Costa ReIs JúNioR

comportamental busca "especificar a natureza da realidade objetiva como ela aparece para os seres humanos". A questão é, então, promover a convergência entre estas diferentes esferas de investigação. A geografia sônica aparentemente contempla esta mirada analítica. É neste entendimento que se fundamenta o eixo teórico-metodológico deste artigo.

Tendo isto em mente, nosso objetivo é propor um programa de pesquisa que pretende tratar dos comportamentos espaciais do som e do ruído, sendo que assumimos como elementos de nosso modelo as seguintes pressuposições: (i) que som e ruído são percebidos pelo ouvido humano e potencialmente ressignificados em forma de música; (ii) que esse processo age na formação de identidades musicais, e (iii) que essas identidades tanto são configuradas como configuram outros comportamentos espaciais. Para isso, consideramos que seriam três as dimensões que formam os alicerces de uma análise multidimensional do objeto de estudo: a) a dimensão física; b) a orgânica ou fisiológica, e c) a dimensão cultural.

Ademais, trabalhamos com a hipótese ad hoc de que por um tal programa, seria possível sugerir uma geografia da música pautada em "geografia(s) do(s) ruído(s)". Isso, em tese, poderia colaborar à compreensão de que a presença (ou a exclusão) do ruído, bem como a evolução dos juízos interpretativos sobre o que ele significa para os povos, é fator fundamental para a formação de determinadas identidades musicais (presumivelmente, discerníveis numa escala regional e ambiental).

Na sequência, este artigo se divide em cinco seções. Na primeira, sustentamos a relevância de um programa de pesquisa multidimensional, a partir da referência a alguns esforços emblemáticos para uma aproximação entre ciência e filosofia. Nas três seguintes, são caracterizadas as dimensões supracitadas, na intenção de demonstrar as variantes de conhecimento que seriam oportunas a uma abordagem geográfica sintética. Por fim, tecemos considerações sobre os passos que poderiam ser seguidos em um trabalho de cunho prático, quando apresentamos exemplos de propostas metodológicas em "Geografia da Música” - que, a nosso juízo, detêm potencial de aporte à nossa proposta.

\section{Em defesa de uma abordagem integrada, carregada de epistemologia}

Várias expectativas se desenham quando se pretende que uma dada perspectiva de investigação possua uma identidade epistemológica. Aqui nos baseamos numa específica acepção para o sentido de "epistemologia"; em especial, aquela que entende ser próprio desse domínio filosófico uma avaliação atenta acerca dos modos como o conhecimento científico é produzido, por exemplo, identificando os aportes cognitivos envolvidos, o poder das circunstâncias e os recursos conceituais e técnicos de potencial utilidade ao trabalho do cientista (Soler, 2009).

Neste sentido, se um estudo se pretende multifatorial (o que é praticamente uma tradição histórica entre geógrafos), é previsível que se anseie arregimentar tantos aportes disciplinares quantos possam existir vieses apropriados a nos aclarar as dimensões heterogêneas do objeto em constituição. E o presente caso -tratando de uma "tríade" (som-ruído-música) que esteja inscrita particularmente no âmbito da ciência 
Onde o físico encontra o humano: proposição...

Nina Puglia Oliveira, Dante Flávio da Costa ReIs JúNioR

geográfica- parece figurar como de desafio sui generis, uma vez que à articulação (já, por si só, bastante imbricada) dos aspectos fisicalistas e biológicos, exigem-se os suplementos das dimensões sociocultural e espacial. Isto é, a confluência simultânea dos papeis jogados pelos ambientes (enquanto fatores de localização diferencial) e pelas comunidades (enquanto produtoras de universos representacionais também diferenciáveis).

Considerando a tríade mencionada, entende-se que ela sugere uma estimulante investigação se, trazida para o território da Geografia, decidirmos dar-lhe relevo pela perspectiva da percepção ambiental. Porém, está claro, essa decisão também dá margem a que se acumulem as múltiplas dimensões referidas, das essencialmente naturalistas (com suas camadas evolutivas e compósitas) às especialmente humanistas (prevendo um entrosamento que, conquanto se dê noutra escala de complexidade, é impossível anular as ações determinantes das camadas física e biológica). Afinal, a percepção ambiental carrega as ideias automáticas de "ecologia" e de "mente"; ou seja, um modelo ontológico de base, segundo o qual detêm realidade significativa (por um lado) as redes de interdependência das estruturas vivas com o meio físico e (por outro) estruturas vivas de mais elevada complexidade. Isso porque, estas últimas, além de possuírem aparato sensorial, têm a habilidade evolutiva de "aditivá-lo", digamos, por faculdades intelectuais que elaboram representações criativas -normalmente com fins práticos ou estéticos, junto ao grupo social-. Por consequência, estas representações resultam em produtos do tipo cultural, mas cujo significado (embora de uma ordem de realidade bastante peculiar) não tem como emergir sem que ocorra uma subjacente "ação em concerto": a articulação dos fenômenos que, por sua vez, são de uma existência independente da ação criativa da mente.

A história documenta com boas ilustrações, episódios em que personagens praticantes de ciência (notáveis, aliás, por terem contribuído ao desenvolvimento de teorias provadas bem-sucedidas no campo investigado) procuraram entrosar o trabalho científico com reflexões de natureza filosófica -e não apenas restritas a uma discussão sobre método-. Há importantes realizações, em especial, na história da Física do século dezenove; quer dizer, numa época em que, por força do avanço dos aparatos técnicos, voltavam à tona dilemas clássicos sobre o conhecimento da natureza, por exemplo, sobre a possibilidade de acessar, via ciência, a realidade em seu âmago. Grosso modo, tratava-se de requalificar os valores das concepções de tradição empirista, com a busca por informações mais seguras acerca do processo de produção de conhecimento a partir do mecanismo sensorial. E, o quanto conclusões melhor estabelecidas dariam reforço ao realismo ou ao instrumentalismo pragmatista (Baldo e Haddad Junior, 2008).

Nomes importantes nisso encontramos entre os que vivenciaram a cena germânica de questionamento do tradicionalismo filosófico, encarregados de buscar um destino mais funcional àquilo que a literatura chamaria Continental Philosophy. Entre eles, Hermann von Helmholtz (1821-1894), Ernst Mach (1838-1916) e Hermann Hertz (1856-1925). Empenhados em demonstrar a ação coordenada dos processos físicos e mecanismos fisiológicos, promoveram a sofisticação de um modelo dual de conhecimento em que a realidade física é justificada pela percepção sensível desta realidade; e, por conseguinte, contribuíram a dar os contornos de uma filosofia científica. Mach, em especial, é o autor da célebre Análise das Sensações (Die Analyse der Empfindungen, 1886) - obra que contou com várias edições e reimpressões, motivadas pelos perseverantes estudos do austríaco. Mach tinha 
Onde o físico encontra o humano: proposição...

Nina Puglia Oliveira, Dante Flávio da Costa ReIs JúNioR

uma obstinação: por um sistema teórico respaldado em experiência empírica, demonstrar a base material (física e fisiológica) dos fenômenos psíquicos. Enquanto seus compartes alemães também procuraram consagrar seus experimentos a essa meta dúplice de fazer avançar o conhecimento científico dos fenômenos biofísicos e de propor um intercâmbio frutífero entre a prática da ciência e a especulação filosófica (Veal, 2005). Ou seja, Helmholtz e seu aluno Hertz foram personagens que, tal como Mach, acabaram demonstrando que um conhecimento "confiável" da realidade poderia residir na demonstração de uma certa correspondência entre o físico e o fisiológico. Daí os estudos que empreenderam sobre os fenômenos da visão e da audição: uma Ótica e uma Acústica alimentando (e sendo alimentadas) pelas teorias fisiológicas do fenômeno respectivo.

Mas cabe frisar um detalhe muito significativo relacionado à produção científica de Helmholtz. Ele investiu esforços em chegar a uma "teoria da música" a partir de um fundamento de ordem naturalista: a "sensação de tom", tratado em termos de fisiologia. Não por acaso, o alemão é o pioneiro de uma verdadeira "epistemologia da audição" (Kursell, 2013).

Regressando à tríade, mas nos detendo na primeira dupla (som-ruído), insistimos na necessidade de não negligenciar os aportes parciais que vêm de dois campos consagrados. Respectivamente, o da Física e o da Fisiologia. É certo que os estudos de percepção ambiental que se alinham numa ótica de ciência social ou humana, por praticamente advogarem a independência do universo simbólico para com o substrato físico, raramente admitem o valor desses aportes. Nós discordamos frontalmente.

O modelo epistemológico que defendemos, baseado na ontologia de camadas que foram emergindo evolutivamente, não se vê em condições de negar, por exemplo, uma "psicofísica da audição” (Hoffmann e Löbe, 2019), na medida em que essa instância parcial da percepção é fundamental para instalar as relações mais complexas atinentes à existência dual organismo-meio (Turvey, 2019).

A frente psicofísica prova-se crucial porque, em última análise, os efeitos culturais que podem interessar diretamente um cientista "do humano" apenas encontram materialidade porque existem "estimulantes sonoros"; e, por conseguinte, "percepção ativa” (Matthen, 2015). Mesmo porque, dentro de uma camada bem informada acerca da interação de fenômenos físicos e fisiológicos, não faz sentido desdenhar o que indicam estudos respaldados sobre percepção auditiva -e, mais especificamente, "audição espacial" (Darwin, 2008) - que, como se deduz, teria muita afinidade com os desígnios de uma pesquisa sobre meio ambiente e saúde. Do mesmo modo, estudos sobre "indicadores de ruído ambiental" (Cowan, 1994) são fornecedores de conceitos técnicos amplamente úteis para os geógrafos que queiram executar levantamentos em campo (mensurações ou enquete). Indicadores tais como os de "exposição sonora", "harmonia", "sensação de tom" etc. (Vogel, 1993); os quais podem estimular inferências de grande valia dentro de uma "fisiologia acústica" coordenada a interpretações (de fato mais requintadas) como a de uma "paisagem sonora". Confluência estimulante na qual o fenômeno "música" pode ser tomado como possuidor uma função representacional e, portanto, comunicativa.

A muitos pode soar descabido que, no intuito de acessar a música como dimensão linguística ou estética do som ou como registro humano documentado arqueologicamente, recorra-se a uma acústica fisiológica, por exemplo. O mais comum é explorar a subjetividade 
Onde o físico encontra o humano: proposição...

Nina Puglia Oliveira, Dante Flávio da Costa ReIs JúNioR

associada aos gêneros ou preferências, ou o caráter situado destas ocorrências. Contudo, mesmo que estes estudos explorem ricos matizes, geralmente desconhecem que parte significativa da explicação da "localização dos sons" encontra subsídio numa "psicoacústica" (Moore, 2007). Ou seja, num campo de estudos experimentais que já oferece modelos descritivos híbridos. Modelos articulando fenomenologia física (encerrada pelos próprios estudos de parâmetros acústicos) com mecanismos anatômico-funcionais e, por conseguinte, tratando de sistemas vivos que apresentam essa intrigante capacidade de conceber respostas neurais aos estímulos (Seikel, King e Drumright, 2010).

Logo, mesmo que os estudiosos desejem mirar em especial o fenômeno complexo música como "comportamento simbólico" (Merriam, 1980), inclusive podendo priorizar os "conteúdos emocionais" interligados a ela (Morley, 2013), o que defendemos é que pode ser imensamente elucidativo tomar contato com conhecimentos substanciais produzidos, por exemplo, em "bioacústica animal" (Fletcher, 2007).

Há, ainda assim, uma histórica resistência por parte dos estudos culturais em incorporarem informação técnica advinda dos estudos naturalistas. Superá-la é necessário. E, sobretudo, em campos que se pretendem mais complexos e de natureza interdisciplinar como a Geografia. Um emblemático exemplo de superação ocorreu quando estudiosos da filosofia da mente deixaram de negligenciar o que vinham acumulando as investigações teóricas e experimentais em neurociências.

A questão é que, em se tratando de uma ciência multidimensional, seu praticante pode ficar tentado a pensar que deve ir à caça de modelagens explicativas "parciais"; cabendolhe, em seguida, encontrar as arestas de contato que favoreçam uma abordagem de cunho particularmente espacial. Afortunadamente, porém, uma consulta a manuais de pesquisas aplicadas em ciências da natureza é reveladora: ali já aparece definida uma série de estudos "miscigenados" onde, por exemplo, o fenômeno acústico tanto pode constar em pesquisas sobre instrumentos musicais, quanto pode fundamentar a análise da faculdade animal da escuta.

\section{As três dimensões da paisagem sonora}

\section{A Dimensão Física: som e ruído}

À acústica física interessa tratar de elementos estruturais que auxiliam o cientista a caracterizar princípios operantes na manifestação e dinâmica de fenômenos materiais. Energia, intensidade, estados não-estáveis, entropia, meios dissipativos, equações de onda... Termos que podemos, a princípio, repelir de nossas argumentações, relegandoos aos "especialistas", na verdade não apenas envolvem representações técnicas que são úteis às análises de cunho ambiental, mas são a bem dizer linguagens da ciência que possuem um sentido potencial que é relativamente amplificável. Portanto, é possível que encontremos, em meio a um vocabulário à primeira vista esdrúxulo, interessantes parâmetros fisicalistas com notável serventia a nossos estudos. Em especial, é claro, aqueles que qualifiquem/quantifiquem o espaço em sua materialidade.

Sabe-se, por exemplo, que em geral os meios de transmissão não são homogêneos; que apenas algumas porções do espaço o são. E esse é um dado potencialmente relevante. 
Onde o físico encontra o humano: proposição...

Nina Puglia Oliveira, Dante Flávio da Costa ReIs JúNioR

Assim como várias outras características físico-ambientais: espaços fechados, com obstáculos, transicionais. Porque, nessas variantes, torna-se necessário distinguir as zonas de passagem entre um meio e outro, cujos objetos podem possuir "elasticidade" diferencial: maior ou menor fluidez, penetrabilidade, rigidez (Lefebvre, 1999). Um programa de pesquisa que incorpore conhecimentos sobre o som em sua dimensão de física acústica encontraria bom ajuste a uma abordagem geográfica se soubermos dar o devido relevo às "condições de fronteira" inerentes ao mundo material.

O som é um fenômeno da natureza que, ao longo da história humana, mesmo diante de suas heterogeneidades intrínsecas, foi sendo classificado, incorporado, reproduzido e produzido de diferentes maneiras, usando-se variadas técnicas e ferramentas; e resultando em (dentre muitas outras coisas) "música”. Dentre os autores que tratam do que poderíamos denominar aqui complexo som - paisagem sonora - música, para este programa de pesquisa salientamos os trabalhos de Raymond Murray Schafer (2011a, 2011b) e José Miguel Wisnik (1989).

Wisnik (1989:17, grifo do autor) descreve o fenômeno sonoro como "o produto de uma sequência rapidíssima (e geralmente imperceptível) de impulsões e repousos, de impulsos (que se representam pela ascensão da onda) e de quedas cíclicas desses impulsos, seguidos de sua reiteração". Assim sendo, quando cessado o movimento, cessa também o som resultante dele. Logo, o silêncio também é um elemento constituinte do som, pois é dele que o som nasce e é nele que o som repousa. Estas definições de som e silêncio encontram correspondência nas de Schafer (2011b).

Os dois autores também apresentam o conceito de ruído. Nas palavras de Schafer (2011b:56-57), ele é “o som indesejável. (...) Não há outro meio para defini-lo”. E explica que, por vezes, o fenômeno sonoro "dissonância" é considerado como sinônimo de ruído, embora faça a ressalva que "consonância e dissonância são termos relativos e subjetivos” (Schafer, 2011b:57). Esta é uma ideia que já aparece desde Schoenberg (2001:58, grifo do autor), quando este diz que "as expressões consonância e dissonância, usadas como antíteses, são falsas”; fato que encontra sólidas evidências na ciência acústica.

No entanto, cabe fazer uma ressalva importante sobre a diferença conceitual entre ruído e dissonância. A onda sonora tem comportamento espectral, o que significa que o som é um feixe de componentes ondulatórios em torno de uma frequência fundamental. É a frequência fundamental que define o que chamamos de "nota musical". No campo da teoria musical, a frequência fundamental -ou seja, aquela que define a nota musical percebida pelo ouvido, porque se sobressai em relação às frequências secundárias da onda- é chamada de "tônica" ou fundamental (Siedenburg, Saitis e McAdams, 2019). Quando duas ou mais fontes sonoras vibram, há uma fusão das frequências individuais resultando em um amálgama sonoro. Segundo Wisnik (1989), a natureza oferece duas possibilidades de experiência sonora: os "complexos ondulatórios cuja sobreposição tende à estabilidade, porque dotados de uma periodicidade interna, e complexos ondulatórios cuja sobreposição tende à instabilidade, porque marcados por períodos irregulares, não coincidentes, descontínuos" (Wisnik, 1989:26-27). Em síntese, complexos ondulatórios regulares resultam em consonâncias; complexos ondulatórios irregulares, em dissonância.

Diante do exposto, nota-se que é essencial compreender a complexidade da onda sonora e seu comportamento mutável. A esse respeito, os estudos do musicólogo e 
Onde o físico encontra o humano: proposição...

Nina Puglia Oliveira, Dante Flávio da Costa ReIs JúNioR

professor da Universidade de Hamburgo, Rolf Bader (2013), são esclarecedores e dão conta que modelagens simples não são capazes de explicar o fenômeno sonoro musical em sua magnitude. Organizador do livro Music, Perception, Performance, Bader (2013) procura discutir conceitos básicos pertinentes aos campos da acústica musical, psicologia da música e teoria musical. Com base em experimentos com a performance de instrumentos musicais, ele demonstra as descontinuidades nos padrões vibracionais e, a partir disso, sugere sistemas que, segundo ele, permitem compreender as "estruturas das performances" sonoras que seriam atinentes às distintas identidades musicais, mundo afora. A corrente metodológica adotada chama-se "musicologia sistemática".

Para Bader (2013), as abordagens lineares conhecidas na ciência acústica e na psicologia parecem ser boas alternativas para transcender os modelos tradicionais e, assim, construir uma perspectiva transdisciplinar e mais aprofundada sobre o fenômeno sonoro. O autor deixa claro também que esta linha de pensamento admite que sua proposta de análise perpassa a percepção de sons e a concepção de música enquanto linguagem. Ele denomina essa abordagem de "musical Gestalt", em uma analogia à vertente Gestalt da psicologia. Em suma: para compreender o processo de produção musical em sua magnitude, é preciso conhecer a fundo as variáveis que o compõem.

Outra variável relevante para os estudos de percepção sonora é o timbre. Siedenburg et al. (2019) apontam que a evidência observada por Helmholtz sobre o caráter espectral da onda sonora é que abriu os horizontes para investigar a questão do timbre: "a qualidade da parte musical de um som composto depende unicamente do número e da força relativa de seus tons parciais simples, e não respeita a diferença de fase" (Helmholtz, 1877 apud Siedenburg et al., 2019:6). Estudos recentes da Acoustical Society of America sobre a percepção humana dos sons, fundamentados em acústica, fisiologia do som, neurociência e psicologia, demonstram que o timbre é o parâmetro da onda sonora mais adequado para compreender a percepção dos sons captados pelo ouvido humano. A obra de Siedenburg et al. (2019) é um exemplo de sólida referência para detalhar aspectos deste quesito. No capítulo intitulado The perceptual representation of timbre, o autor Stephen McAdams (2019) pontua que, na ciência acústica, timbre é uma especificidade da onda complexa que forma o som. As propriedades de cada timbre envolvem aspectos tanto sonoros como auditivos, e podem ser investigadas segundo os parâmetros brilho, aspereza, ataque, opacidade e “desarmonicidade» (inharmonicity).

McAdams (2019:24, tradução nossa) menciona também estudos de Wessel que apontaram que "a gênese do timbre está não apenas nas propriedades espectrais, mas também nas propriedades temporais. Esta abordagem leva a uma concepção de timbre como um conjunto das dimensões de assimilação representadas em um 'espaço tímbrico". Salienta, ainda, que, atualmente, esta linha de pensamento é considerada reducionista, pois a neurociência já demonstra que a análise sobre o timbre é complexa e não deve ater-se a uma "coleção de propriedades individuais", mas que deve ser analisada com um olhar multidimensional. Por isso mesmo, McAdams (2019:23-24) é taxativo ao afirmar que timbre é uma experiência de percepção, e não uma experiência fisiológica exclusivamente, explicando, ademais, que a representação da percepção do timbre no sistema auditivo está atrelada à identificação das fontes sonoras, sejam elas a voz humana, instrumentos musicais ou sons ambientes. 
Onde o físico encontra o humano: proposição...

Nina Puglia Oliveira, Dante Flávio da Costa ReIs JúNioR

Estas colocações sobre timbre nos indicam que ele pode ser uma categoria imperativa para compreender a percepção de sons pelo ouvido humano, pois ele, além de ser o que permite a identificação da fonte sonora, é a propriedade intrínseca que a diferencia de outras fontes. E é justamente neste ponto que se mostra plausível também conectar uma abordagem geográfica sobre a percepção dos sons. Para isso, investigações sobre percepção da paisagem sonora têm-se mostrado pertinentes.

Schafer (2011a) define "paisagem sonora" como o conjunto de sonoridades em um determinado ambiente. Para ele, "a paisagem sonora é qualquer campo de estudo acústico" (Schafer, 2011a:23). Portanto, "o que o analista da paisagem sonora precisa fazer, em primeiro lugar, é descobrir os seus aspectos significativos, aqueles sons que são importantes por causa de sua individualidade, quantidade ou preponderância" (Schafer, 2011a:25-26). A "individualidade" aí colocada reforça a inferência sobre a centralidade do timbre neste processo. $\mathrm{O}$ autor então classifica os sons em três categorias básicas: sons fundamentais, sinais e marcas sonoras. A diferença entre elas está justamente nas distintas representações que cada uma delas assume, na forma em que comunicam algo a alguém e no conteúdo que cada uma delas comunica aos seres humanos.

A esse respeito, o geógrafo inglês Douglas Pocock, no artigo Sound and the geographer (1989), aponta que paisagem sonora é, a priori, um conceito multidisciplinar usado tanto em ecologia sonora quanto na geografia, dada a evidente correspondência com o conceito geográfico de paisagem. A diferença está no fato de que a paisagem "geográfica" está ligada à percepção que o indivíduo tem do ambiente ao seu redor, através especialmente do sentido da visão, enquanto a paisagem sonora, como se depreende, se realiza por meio da percepção do ambiente a partir dos sons captados pelo sentido da audição. Parafraseando Ong, Pocock pontua que "o som é um mundo de situações", enquanto "a visão é um mundo de objetos” (Pocock, 1989:193, tradução nossa).

Nesse mesmo texto, Pocock (1989) lança uma reflexão acerca do quão negligenciada é a variável som em análises geográficas sobre espaço, lugar e meio ambiente, diante do incontestável fato de vivermos em um mundo intrinsecamente permeado por sons e ruídos. Bem, ele atribui essa negligência à dominância que o sentido da visão (e a análise daquilo que é visto) tem na ciência geográfica, em detrimento de análises embasadas em outras variáveis. Tal perspectiva é atestada pelo fato de o conceito de paisagem ser um pilar da Geografia desde a sua gênese enquanto ciência, além da inequívoca abundância de estudos geográficos que têm a paisagem como principal conceito ou categoria de análise. A proposta de Pocock é, então, munir a ciência geográfica de insumos para investigar a questão do som, aproximando a Geografia das investigações em ciências sociais e artes. Tendo isso em vista, o autor faz uma explanação concisa sobre três aspectos que considera relevantes para uma análise do som sob a perspectiva da geografia sônica: o dinamismo da paisagem sonora, que envolve toda uma gama de aspectos sensoriais e neurológicos; o primitivismo do sentido da audição em relação ao sentido da visão (aspecto este que será melhor explanado na seção seguinte), e o fato de os seres humanos estarem no intercurso entre o som e o silêncio.

O artigo Pour une géographie des milieux sonores, de Frédéric Roulier (1999), traz uma seminal contribuição para a "geografia do ruído". Importante ressaltar, de pronto, que o geógrafo francês diferencia geografia do ruído da "geografia dos ruídos". Para ele, o primeiro conceito está atrelado a questões relacionadas aos "incômodos" sentidos pelos 
Onde o físico encontra o humano: proposição...

Nina Puglia Oliveira, Dante Flávio da Costa ReIs JúNioR

indivíduos na percepção deste tipo de som, ao passo que, no segundo caso, o interesse se volta para compreender as "variações espaciais dos ruídos", ou seja, a preocupação é com a incidência de ruído no espaço. Em ambos os casos, Roulier considera imprescindível ao geógrafo tomar o fenômeno sob a ótica da geografia cultural, ângulo também defendido por Pocock (1989). Roulier (1999:6coloca, ainda, que "a geografia do ruído está particularmente interessada nos contextos e efeitos situados da poluição sonora" nos contextos de controle administrativo e da origem do desconforto, pois

(...) este é o contexto das questões que envolvem o espaço sonoro. O ruído extremo é capaz de desencadear questões coletivas locais sobre o espaço. Ela se torna o catalisador da luta entre os moradores locais e as empresas de transporte aéreo, gerentes de boates, concessionárias de auto-estradas, etc. (Roulier, 1999:6, tradução nossa).

É exatamente essa abordagem "da luta administrativa" a adotada no Projeto Acústico de Schafer (2011a). O pesquisador, professor e compositor canadense, através de medições dos níveis de ruído em diversos lugares do mundo, procurou não só conhecer a diversidade de paisagens sonoras, mas, sobretudo, contribuir para a elaboração de políticas públicas de melhoria da saúde coletiva, a partir dos efeitos que os índices de poluição sonora podem ter na saúde humana.

Diante do exposto, fica evidente que conhecer e analisar uma paisagem sonora constituise em questão chave para compreender os elementos sonoros formadores das múltiplas identidades musicais regionais. Contudo, para desvendar a formação de uma identidade musical é imprescindível recorrer à investigação sobre a percepção humana do fenômeno sonoro (Schafer, 2011b).

\section{A Dimensão Orgânica: da fisiologia da audição à percepção de ruído}

Sobre a percepção humana dos sons, o livro The Effects of Sound on People, do engenheiro acústico estadunidense James P. Cowan (2016), nos apresenta uma ampla e detalhada exposição sobre fisiologia da audição e sobre os mecanismos de percepção humana de sons. De pronto, este autor afirma que a ciência acústica é, a priori, multidisciplinar, pois compreender fisiologia do som necessariamente inclui conhecimentos de física mecânica e elétrica, e dos seus componentes biológicos e psicológicos. Ele também ressalta que qualquer discussão sobre os efeitos do som em humanos requer uma "explanação sobre os parâmetros associados à geração, propagação, descrição e percepção de sons” (Cowan, 2016:1, tradução nossa).

Certos aspectos anatômico-funcionais muito particulares do processo auditivo tendem a nos parecer dispensáveis quando o objetivo é estudar um fenômeno para o qual bastará simplesmente "pressupô-los" -porque ele se situa no que entendemos ser uma outra camada de relações (psicolinguísticas e socioculturais). Ou seja, é suficiente termos por certa a transmissão da onda sonora, da energia acústica. Elas são um "fato". Nesse sentido, conhecer a função da cóclea, da pressão transmitida através de membranas e paredes ósseas, do nível de potássio na endolinfa etc., é, para um/a geógrafo/a, supérfluo ou excedente. Por outro lado, manuais técnicos de fisiologia auditiva registram informações calcadas em modelagens teóricas ou em evidência experimental, que a ele podem ser úteis se quiser um maior aclaramento acerca das funções do ouvido médio, 
Onde o físico encontra o humano: proposição...

Nina Puglia Oliveira, Dante Flávio da Costa ReIs JúNioR

por exemplo (Pickles, 2012). Pois, dado que seus músculos operam uma espécie de controle automático dos estímulos (modulando a transmissão de sons), esse aparato sensitivo é um excelente indicador para o cientista do espaço apreciar o efeito de ruídos ambientais, cujas variadas faixas de intensidades (algumas podendo desencadear ressonâncias perturbadoras) ativam o link entre as respostas mecânicas (da membrana basilar) e as respostas eletrofisiológicas (do nervo auditivo).

A esse respeito, em seu capítulo sobre percepção de sons, Cowan (2016) é bastante elucidativo. $\mathrm{O}$ aparelho auditivo humano é dividido em três partes que executam diferentes funções no processo de audição. Primeiro, o ouvido externo, responsável pela localização (diferença do tempo de chegada do som em cada ouvido), ressonância e proteção das partes mais profundas do ouvido, sobretudo dos tímpanos. O ouvido médio, formado pelos três menores ossos do corpo humano, que carregam a vibração do tímpano para a cóclea, amplificam o som para amortecer o sinal acústico entre os ouvidos externo e interno, e regulam a pressão auricular através da trompa de Eustáquio. É neste segmento do ouvido, aliás, que a energia sonora é transformada em energia mecânica. Por fim, a terceira seção é o ouvido interno, a parte mais profunda do aparelho auditivo. É lá que se localiza a cóclea, órgão recheado de fluidos que transforma as vibrações mecânicas em sinais elétricos que são transmitidos para o cérebro, através de uma série de ligações químicas que ocorrem no sistema vestibular (Cowan, 2016:37-43). A Figura 1 ilustra o mecanismo de audição humana:

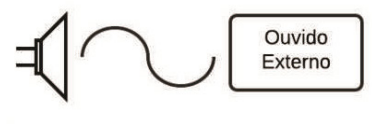

Fonte Sonora

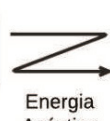
Acústica

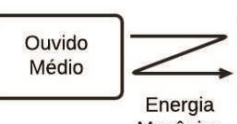

Mecânica

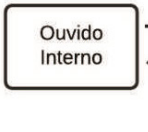

Ouvido

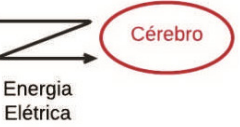

Figura 1. Modelo do mecanismo de audição em seres humanos. Fonte: elaboração própria.

A respeito dos efeitos da exposição ao ruído na audição humana, Cowan (2016:48) esclarece que a região mais afetada por altas taxas de ruído é o sistema vestibular. Um possível efeito colateral desta situação é o zumbido. Não há consenso sobre a causa do zumbido, mas é sabido que, em níveis extremos, pode causar efeitos debilitantes crônicos no sistema auditivo e até a perda da audição. Outro efeito colateral possivelmente associado à decorrência de alta exposição ao ruído é a hiperacusia, condição na qual o indivíduo desenvolve hipersensibilidade a certas faixas de frequência sonora. Em suma, a superexposição ao ruído não só altera como até prejudica a capacidade de percepção sonora.

Vale retomar aqui a diferença conceitual entre ruído e dissonância, uma vez que o primeiro é um fenômeno natural inerente à onda sonora e o segundo se refere à experiência sonora, resultante da percepção de sons considerados incômodos pelo ouvinte. As células capilares do ouvido interno estão conectadas a fibras nervosas que se combinam no nervo auditivo (Cowan, 2016:42), o que nos indica que é nesta etapa do fenômeno auditivo que a informação sonora é transformada em sinapses nervosas, que numa próxima etapa, são processadas pelo cérebro do ouvinte. Portanto, ruído é também um fenômeno natural, enquanto a dissonância -ou, simplesmente, "barulho"- configura-se no processo de interpretação da percepção sonora. 
Onde o físico encontra o humano: proposição...

Nina Puglia Oliveira, Dante Flávio da Costa ReIs JúNioR

Isso posto, no que se refere à abordagem geográfica, Pocock (1989:193) entende que o som é uma "perturbação sonora que produz vibrações ou ondas de pressão no ar que nós registramos à medida que as convertemos em sinapses nervosas". E ainda acrescenta que, embora ordinariamente se utilize as definições de som e de ruído como dois conceitos distintos (considerando o ruído como o som "indesejável", incômodo), tal diferenciação não existe. "O que interessa, aqui, é o som como informação - para ser descrita e experienciada”, completa Pocock (1989:193, tradução nossa). Assim, a intenção é compreender o fenômeno sonoro, sobretudo como conteúdo e não tãosomente como forma. O já citado Schoenberg (2001) valida essa ideia. Para ambos os autores, então, som é, ao mesmo tempo, fenômeno natural e experiência humana. Mas, por isso mesmo, ele não é menos um fenômeno "geográfico", na medida em que se mostra como uma variável relevante a ser considerada quando se pretende uma análise de interface. Isto é, o fenômeno recai no âmbito da Geografia precisamente porque é próprio dessa disciplina avaliar o estabelecimento de conexões entre a disponibilidade de recursos (no meio natural) e a ocupação e usufruto destes pelas coletividades humanas. Algo que, aliás, recobra a importância de um projeto, já clássico, de reaproximação das geografias física e humana.

Para Cowan (2016:2), "o principal fator de distinção entre esse tipo de energia [sonora] e todas as outras é que ela pode ser detectada por um mecanismo auditivo e interpretada para alguma forma de ação ou comunicação". Infere-se daí que a música é uma das várias possíveis resultantes da tradução cognitiva de um processo da percepção humana da natureza. Esta tradução é transformada em linguagem. E, neste caso, uma linguagem artística, pois envolve a capacidade humana de abstrair e expressar, através de sons, uma representação do mundo. Tal concepção se apoia em Schoenberg (2001). Segundo ele,

A arte é, em seu estágio mais elementar, uma simples imitação da natureza. Mas logo torna-se imitação num sentido mais amplo do conceito, isto é, não mera imitação da natureza exterior, mas também da interior. Em outras palavras: não representa, simplesmente, os objetos ou circunstâncias que produzem a sensação, senão, antes de tudo, a própria sensação, eventualmente sem consideração ao "o que", "quando" e "como" (Schoenberg, 2001:55).

Na ciência geográfica, este ponto de vista do compositor austríaco encontra eco no conceito de percepção apresentado por Yi-Fu Tuan no livro Topofilia (1980). Para Tuan (1980:4), percepção "é tanto a resposta dos sentidos aos estímulos externos, como a atividade proposital, na qual certos fenômenos são claramente registrados, enquanto outros retrocedem para a sombra ou são bloqueados”. A percepção, juntamente com atitude e visão de mundo, forma a tríade das categorias essenciais para a assimilação do conceito de "topofilia", que, por sua vez, corresponde ao "elo afetivo entre a pessoa e o lugar ou ambiente físico” (Tuan, 1980:5).

Ao afirmar que "duas pessoas não vêem a mesma realidade" e que "todos os seres humanos compartilham percepções comuns, um mundo comum, em virtude de possuírem órgãos similares", Tuan (1980:6) parte do princípio de que os seres humanos são, ao mesmo tempo, indivíduos e unidades de um todo social. Isso nos permite concluir que o processo de percepção está impregnado de elementos que partem tanto da esfera individual como da esfera coletiva de apreensão do mundo 
Onde o físico encontra o humano: proposição...

Nina Puglia Oliveira, Dante Flávio da Costa ReIs JúNioR

externo. Nesse sentido, novamente é enfatizada a perspectiva multidimensional. E ela parece exigir que, para compreendermos o todo, analisemos as partes; o que, a nosso juízo, não teria por que ser distinto no tocante ao fenômeno perceptivo de paisagens sonoras.

Ainda de acordo com Tuan (1980:10), o ouvido humano "está adaptado especificamente para a sobrevivência da espécie e geralmente para atrair o mundo através dos sinais auditivos" e "geralmente somos mais sensibilizados pelo que ouvimos do que pelo que vemos". O autor deduz, então, que isso se deve a dois fatores: não ser possível "fechar os ouvidos", do mesmo modo como o seria para os olhos; e pelo fato de que o sentido da audição é o primeiro a ser desenvolvido durante período gestacional, cumprindo, por isso, um papel essencial na questão da configuração dos mecanismos de sobrevivência da espécie. Segundo Tuan (1980:10), "parece verdade também que o bebê é sensível ao som, fazendo distinções entre o agradável, o confortante e o perturbador, muito antes que possa visualmente discriminar com alguma sutileza”. Esta linha de raciocínio é corroborada por Cowan (2016) e aprofundada no artigo Paisagens sonoras: possíveis caminhos aos estudos culturais em geografia, assinado por Marcos Alberto Torres e Salete Kozel (2010). No texto, os autores afirmam que antes de enxergar o mundo externo, o embrião humano já escuta o movimento dos órgãos e a voz da mãe. Ou seja, a percepção do mundo externo através da audição é antecedente à percepção através do sentido da visão; o que não só ratifica o raciocínio de Tuan, como demonstra a potencial centralidade do fenômeno auditivo para a percepção e (re)produção de paisagens sonoras.

Os seres humanos fazem um uso limitado de seus sentidos. Nas sociedades contemporâneas, parecem ser levados a confiar particularmente na faculdade visual e pouco menos nos demais sentidos (Tuan, 1980). A percepção sensível do som provoca associações; relaciona o que é onda mecânica vibracional com um aparato orgânico (o ouvido), do que deriva não somente o mundo sensorial (e a consequente dedução de uma realidade externa), mas o mundo representacional (Schoenberg, 2001). Este mundo, em especial, produz linguagem (por exemplo, artística) mediante símbolos. Assim, no arco que vai da natureza à cultura, o fato incontestável é que o som (elemento físico que atua diretamente sobre o ouvido) é, por excelência, a matéria da música.

Portanto, parece razoável supor que a investigação sobre a simbiose entre os elementos desta tríade nos levaria a uma compreensão ampla e minuciosa da geografia da música, posto que sob um paradigma multidimensional.

\section{A Dimensão Cultural: o fazer musical e a hipótese da emergência de identidades}

Sob um viés tipicamente antropológico, mas compreendendo a transversalidade com estudos em linguística e psicologia evolutiva, é possível dizer que a música detém um notável atributo de comunicação. Pretenda-se ou não sustentar que este atributo foi conscientemente deliberado no curso das civilizações, a verdade é que é bastante razoável entender que se trata aí de um tipo especial de comunicação que se efetuou mediante a exploração de "significados simbólicos" aceitos, de modo tácito, pelos membros de uma dada comunidade. Isto é, a música teria sido divisada como uma investidura eficiente para representar esse compartilhamento de símbolos. 
Onde o físico encontra o humano: proposição...

Nina Puglia Oliveira, Dante Flávio da Costa ReIs JúNioR

Como no caso de outras expressões artísticas, o produto musical veicula atitudes e valores; reflete uma organização social: “(...) a música é um meio de entender as pessoas e o comportamento e, como tal, é uma ferramenta valiosa na análise da cultura e da sociedade" (Merriam, 1980:13, tradução nossa).

Estudos sociais e antropológicos sobre música iniciaram trazendo à discussão o fator (se determinante ou não) das "áreas geográficas". Enquanto para alguns pesquisadores a etnomusicologia se fundava como uma ciência sobre as músicas "não europeias", outros rejeitariam a ideia de que a condição geográfica serviria para distinguir o que era para ser considerado musicologia tradicional e o que devia ser entendido mais como estudos "étnicos" sobre músicas e danças populares mapeadas junto a regiões africanas, no extremo oriente ou ainda entre remanescentes de povos originários da América do Norte.

O panorama da geografia da música feito por Lucas Panitz (2010) em sua dissertação de mestrado nos indica que, inicialmente, este campo de estudo, representado mormente por Friedrich Ratzel e seu discípulo Leo Forbenius, restringia-se a investigar a distribuição espacial dos instrumentos musicais e as possíveis variações entre eles. Em sua pesquisa sobre difusão e morfologia de tambores usados por povos africanos, Frobenius, juntamente com os colegas etnólogos Fritz Graebner e Wilhelm Schmidt, desenvolve o conceito de "círculos culturais", que permitiu estabelecer regionalizações no continente correspondentes aos ciclos de difusão das etnias africanas (Panitz, 2019).

Na França, o pesquisador de maior destaque nesta época foi Georges Gironcourt, que defendia a ideia de que, ao fornecer informações sobre as formas musicais no tempo e no espaço, a Geografia da Música contribuiria para analisar "a fixação e a mobilidade de sociedades e civilizações” (Panitz, 2010:50). Ainda segundo Panitz (2010:51, grifos nossos), "a principal diferença entre Frobenius e Gironcourt é que enquanto o primeiro reconstituía períodos históricos e pré-históricos através da cultura material, ao segundo também interessavam as formas não materializadas como os ritmos, o canto e as danças tradicionais".

Atribui-se também aos franceses o foco dado ao território. Neste contexto, Panitz (2010) destaca o trabalho de Jacques Lévy, que estuda o panorama da música erudita europeia, com maior ênfase nos processos sociopolíticos que atravessaram o movimento de vanguarda na música, sobretudo em Viena, terra natal do supracitado compositor serialista Arnold Schoenberg.

Posteriormente, é por meio de Carl Sauer que se introduz o viés analítico-cultural, mas ainda muito voltado para o olhar sobre lugar e localização. Sauer apropria-se do conceito de Áreas Culturais através de seu amigo antropólogo Alfred Kroeber, que por sua vez é pupilo de Franz Boas. No entanto, Lily Kong (1995) pertinentemente pondera que, embora representem um avanço conceitual em relação aos alemães e franceses, estes estudos da escola de Berkeley ainda não apresentavam sofisticação teorética e tampouco metodológica.

A renovação na geografia cultural daria lastro a abordagens mais abrangentes e críticas. Os contornos disso são impetrados a partir da realização de congressos promovidos por associações de geógrafos, bem como da edição de uma série de publicações coletivas. 
Onde o físico encontra o humano: proposição...

Nina Puglia Oliveira, Dante Flávio da Costa ReIs JúNioR

E dentre as vertentes realimentadas (ou originalmente surgidas) estaria o campo dos estudos da música. A música, enquanto fenômeno geográfico e social, começaria a ser explorada sob múltiplas facetas e, às vezes, dentro de um panorama bastante pluridisciplinar. Ilustra o fato o importante livro The Place of Music, organizado por Leyshon, Matless e Revill (1998) a partir da Conferência homônima que reuniu pesquisadores de várias áreas e partes do mundo, em 1997.

Após a conferência, outros nomes desta cena de uma nova e efervescente geração de pesquisadores são Peter Nash e George Carney (1996), que estabeleceriam sete eixos temáticos que, acreditavam, seriam norteadores das investigações em geografia da música na contemporaneidade. Paralelamente, ganha relevo também a agenda de pesquisa proposta pela geógrafa singapurense Lily Kong (1995), que advoga pela multidisciplinaridade nos estudos musicais, tradicionalmente vinculados à antropologia e à sociologia, incorporando ao escopo teórico da geografia cultural renovada, sobretudo a música popular. Para isso, a autora sugere a inclusão de temas como: o conteúdo político engendrado tanto no contexto, quanto na forma e conteúdo musicais; a questão da música enquanto ferramenta de formação/afirmação de identidade(s), a música enquanto instrumento ideológico do imperialismo e da globalização. Outro ponto importante levantado por Kong (1995) é a questão econômica vinculada ao fazer musical que, em vários países, configura-se como uma expressiva atividade produtiva, ${ }^{3}$ seja pela via das atividades artístico-culturais, seja pela via do turismo.

No Brasil, a pedra fundamental da Geografia da Música foi a dissertação de mestrado de João Baptista Mello defendida em 1991. Nas pesquisas brasileiras predominam as abordagens humanística, social e cultural renovada. Conceitos como espaço vivido, geograficidade, lugar, território e região costumam ser os mais aplicados pelos geógrafos brasileiros (Panitz, 2010). Para os fins da nossa proposta científica, destacam-se os trabalhos de Alessandro Dozena, Lucas Panitz, Salete Kozel e Marcos Torres.

Entretanto, o que este panorama nos mostra é que, aparentemente, essas novas correntes não abrangeriam um olhar tão multidimensional como sugerido por Golledge (2006). Nosso programa se propõe ser uma contribuição ao preenchimento desse quesito da multidimensionalidade amplificando, assim, a abrangência da produção do conhecimento geográfico sobre música. Para tal, parte-se da premissa de que a paisagem sonora é um elemento formador da identidade de um lugar e, consequentemente, da identidade dos indivíduos. A paisagem sonora detém, portanto, poder de influência na constituição de sentidos de pertencimento, dado que as sonoridades de um lugar remetem à familiaridade da paisagem.

Este é um ponto de vista defendido por Torres e Kozel (2010), para os quais

(...) a paisagem é um complexo de formas e relações culturais, e à Geografia cabe a busca da compreensão de cada paisagem, não só pela aparência numa leitura estética, mas na busca de desvendar os significados dos lugares e as relações neles e entre eles estabelecidas (Torres e Kozel, 2010:124).

3 A esse respeito, a dissertação de mestrado de Nina Puglia Oliveira (2014) faz uma análise socioespacial do mercado de música em Brasília-DF, Brasil. Disponível em: https://repositorio.unb.br/handle/10482/16210 
Onde o físico encontra o humano: proposição...

Nina Puglia Oliveira, Dante Flávio da Costa ReIs JúNioR

Portanto, a paisagem é um sistema natural, mas também cultural, pois reflete as identidades do lugar e de seus habitantes. Não obstante, cada lugar também projeta especificidades na paisagem. E, no caso da paisagem sonora, isso o torna então parte essencial no processo de transformação de sons (originalmente vinculados ao lugar) em música (referente à paisagem).

Segundo Dominique Crozat (2016:14), em capítulo integrante da obra coletiva Geografia e Música organizada por Alessandro Dozena, a música apresenta-se como tema de análise geográfica na medida em que ela, dentre outras coisas, "oferece um campo de referências para construir identidades individuais e coletivas espacializadas" e "participa da transformação do espaço em território". O autor traz justamente a ideia de "identidade musical", mas inserida em uma acepção contemporânea de identidade, a que supera conservadorismos, por ser múltipla e flexível. Crozat (2016:17-19) segue o raciocínio explicando que "(...) a música é quase sempre vista com referência a algo além dela mesma, como suporte de identificação" e "produz imagens, e na maioria das vezes, imagens dos lugares”. Essa perspectiva encontra eco na elaboração teórica de Wisnik (1989) sobre a "história das músicas", especialmente naquilo que o autor chama de "antropologia do ruído"; bem como conflui com a visão de Schoenberg (2001) de que a música é uma resultante da ação conjunta entre som, ouvido e mundo sensorial. Por fim, Crozat (2016:34) levanta outra questão potencialmente relevante ao afirmar que "a qualidade espacial ou ícone paisagístico que introduza música está ligada aos músicos que a compõem ou tocam (...)”, o que evidencia que a análise em geografia da música deve amparar-se no processo do fazer musical e não somente na perspectiva da apreciação musical.

O que se constata é que já há um esforço dos estudos contemporâneos em Geografia da Música não só pela atualização, mas também pela ampliação dos cânones teóricos da Geografia Cultural tradicional. Depreende-se de Ana Francisca Azevedo (2018) que está em curso uma reconfiguração deste campo de estudo, que objetiva conceber a música enquanto fenômeno comunicativo das idiossincrasias humanas historicamente contextualizadas por meio da

(...) confirmação da ruptura com uma tradição geográfica de aprisionamento da experiência de paisagem à componente visual, permitindo recolocá-la não somente como experiência óptica mas como experiência háptica. Desde este ponto, a problematização dos conceitos de paisagem e cultura acompanharam a própria problematização de um conceito de música que não respondia aos desafios de análise e compreensão da totalidade do fenômeno acústico como componente intrínseca da produção do espaço e do sentido de lugar (Azevedo, 2018:27).

Apropriando-se das palavras de Johann Kroier, Azevedo (2018) enfatiza, ainda, uma "viragem em direção a 'um novo tipo de musicologia cosmopolita através da contextualização da Etnomusicologia em relação à sua própria fonte histórica; a objetivação da música iniciada por Hermann Helmholtz"' (Kroier, 2012 apud Azevedo, 2018:32).

Com base nisso, torna-se ainda mais pertinente compreender o lugar do ruído no desenvolvimento das identidades musicais ocidentais. Conforme explica Wisnik (1989), no decorrer da história humana, o ruído foi excluído do processo de construção das identidades musicais 
Onde o físico encontra o humano: proposição...

Nina Puglia Oliveira, Dante Flávio da Costa ReIs JúNioR

predominantes no mundo ocidental. A música era entendida como um recurso a mais na construção idealizada de um mundo sem conflitos, apregoado sobretudo na Europa. Esta lógica foi interrompida somente no início do século XX, com o desponte de um movimento de renovação da música, expresso por um novo paradigma de composição musical: o Atonalismo. Compositores da chamada Segunda Escola de Viena são apontados como os pivôs desta mudança. Dentre eles, o principal nome é justamente o de Arnold Schoenberg, que, ao escrever seu tratado de harmonia (marco teórico fundamental do Serialismo), rompe definitivamente com a diferenciação entre som musical e ruído (Schoenberg, 2001).

A Revolução Industrial inseriu nas paisagens sonoras europeias uma série de ruídos não naturais, o que segundo Schafer (2011a), inaugurou uma era de ruído ininterrupto. Posteriormente, como consequência da própria Revolução Industrial, o continente experimenta um intenso processo de urbanização, o que acrescenta ainda mais ruídos à paisagem. Paralelamente, surgem as tecnologias de gravação e reprodução de sons. Este cenário complexo e caótico forma o alicerce fundamental para a música atonal do início do século XX, pois, a partir daí, abrem-se os horizontes para a inclusão do ruído como parte "integrante" da música. Algo que, por sinal, terminaria culminando no surgimento da música eletrônica.

Este contexto de transformações culturais e espaciais que retroalimentaram os anseios vanguardistas no universo das artes traz à baila também a diluição das fronteiras entre música erudita e popular. É neste momento histórico que vários novos estilos musicais que são lidos como essências máximas do século XX -como o rock e o rap, por exemplo- tornam-se possíveis. Consequentemente, passa a ser imperativo para os/ as geógrafos/as compreender as dinâmicas e comportamentos espaciais inerentes à produção de música popular.

De acordo com Kong (1995:183, tradução nossa), a ciência geográfica historicamente relegou os gêneros populares a "mero entretenimento, trivial e efêmero", sendo engendrada por um olhar elitista sobre arte e cultura e, citando vários/as autores/as, faz coro com Pocock (1989) e Azevedo (2018) na questão da prevalência de análises geográficas com ênfase no sentido da visão. Seguindo Kong (1995:184, tradução nossa), para além de transmitir experiências ambientais, compreender o fazer musical é relevante porque "a música de uma área específica pode transmitir imagens do lugar. (...) Pode também servir como uma fonte primária útil para compreender o caráter e a identidade dos lugares". A autora também reconhece o atributo dual da música, que é ao mesmo tempo experiência individual e ferramenta de produção e reprodução de sistemas sociais.

Tudo isso posto, mostra-se evidente a necessidade de aproximar abordagens teoréticas com tratamentos naturalistas de propostas metodológicas na linha fenomenológica já consolidada na Geografia Cultural, para compreender de maneira ampla a complexidade espacial do fenômeno música.

\section{Diálogos metodológicos}

Como referido antes, o programa de pesquisa que propomos caracteriza-se, epistemologicamente, por estar fundamentado em um modelo teórico sobre a multidimensionalidade. Nesse sentido, seu aspecto prático, sua metodologia, não se restringe a 
Onde o físico encontra o humano: proposição...

Nina Puglia Oliveira, Dante Flávio da Costa ReIs JúNioR

um único enfoque. Ou seja, não se prendendo a uma argumentação exclusivamente histórico-cultural, tampouco puramente físico-naturalista. A construção metodológica aqui apresentada inspira-se no comportamento espacial proposto por Golledge (2006:75, tradução nossa), que requer "adaptações técnicas de outras disciplinas ou modificações em técnicas já existentes para o uso espacial”, e que reforça a necessidade da coleta de dados primários, sejam eles qualitativos ou quantitativos. Assim sendo, a intenção é seguir, por exemplo, algumas propostas metodológicas já consolidadas, como as verificadas em Panitz (2010) e em Torres e Kozel (2012), e propor a inclusão de outros procedimentos de pesquisa para salvaguardar o caráter multidimensional do objeto de estudo.

Da dissertação de Panitz (2010), que trata da espacialidade da música da macrorregião platina, vários pontos pertinentes podem ser alçados. O conceito de "fenômeno musical" como "conjunto e uma interação de relações (...) que se expressam no fazer musical" (Panitz, 2010:76-77, grifo nosso) e sua mirada humanista-fenomenológica sobre tal fenômeno, que também nos é cara posto que favorece, por exemplo, detectar os sistemas de ações e os sistemas de objetos que o engendram (Santos, 2008). Igualmente sugestivas são as ideias de música enquanto uma das várias possibilidades de representação do espaço e suas decorrentes implicações na (multi)territorialidade. Por fim, saliente-se ainda a questão intrincada, mas crucial, da identidade, a qual exige a consideração das esferas individual e social do termo.

Para Panitz (2010), a cultura é uma totalidade da qual se extraem representações. Estas são difundidas por vários meios comunicativos (da linguagem natural aos veículos técnicos) e servem de referência para a formação de uma identidade coletiva que, por sua vez, influencia na formação de uma identidade individual. Ou, colocando em outros termos: dinâmicas sistêmicas de retroalimentação estariam atuando em processos contínuos.

Na operacionalização de seu estudo de caso, Panitz (2010) inspirou-se na ideia de pesquisa de campo "multi-situado" associada ao antropólogo George E. Marcus. Segundo este intelectual, o/a pesquisador/a deve "seguir" as pessoas, a coisa e a metáfora. Mas Panitz, geógrafo, ainda acrescenta um compromisso a mais (por fim, fundamental): seguir os territórios e as paisagens.

Por sua vez, a proposição metodológica de Torres e Kozel (2012) é igualmente inspiradora. No estudo realizado por esses pesquisadores -acerca do "fandango" (praticado na Ilha dos Valadares/PR)-, o objetivo ali era

(...) estabelecer relações entre a paisagem sonora e elementos do universo de cada morador entrevistado [integrantes de grupos de tocadores de fandango], a partir de suas percepções e memórias acerca da Ilha dos Valadares enquanto espaço de moradia e espaço de representação, e a relação desta com suas localidades de origem, bem como com as localidades que ainda estabelecem contato (Torres e Kozel, 2012:171-172).

O trecho, a bem dizer, posto que indica o recurso a procedimentos interpretativos para a captura de "percepções e memórias", sugere relativo alinhamento dos autores com uma geografia cultural de corte fenomenológico. E a concepção de paisagem sonora 
Onde o físico encontra o humano: proposição...

Nina Puglia Oliveira, Dante Flávio da Costa ReIs JúNioR

que acaba decorrendo da abordagem executada pelos pesquisadores parece fecunda. Constituindo etapas coordenadas, recorreram a entrevistas semiestruturadas, mapas mentais (elaborados por cada entrevistado/a) e técnicas de interpretação de imagem. A este encadeamento de procedimentos, os autores referidos acima dão o nome de "método Kozel".

Todos estes apontamentos metodológicos são assertivos em seus respectivos modelos de investigação; e, certamente, contribuem para a construção metodológica aqui sugerida. As duas pesquisas supracitadas incluem investigações sobre o fazer musical a partir da perspectiva de quem faz música. Porém, ainda carecem de aprofundamento acerca do material sonoro que constituiu a matéria-prima para a produção musical. Daí nossa aposta na necessidade de um programa de pesquisa que recupere, junto a outros campos de produção do conhecimento (distintos, por certo, mas potencialmente cooperativos) -tais como os da ciência acústica, da neurociência, da teoria musical-, os subsídios para conformar uma abordagem integrada e consequentemente, mais idealmente "geográfica". Porque, tenhamos claro, o aporte de conteúdos que eles podem nos fornecer, no mínimo, opera uma melhor iluminação dos aspectos vários envolvidos no processo (humano) de transformar sons e ruídos em música. Algo que, ao que tudo indica, também influencia diretamente na formação de identidades musicais.

Por conseguinte, parece-nos absolutamente coerente um esforço para incluir, na perspectiva prática da coleta e tratamento de dados, expedientes inclusive técnicos, como a medição dos níveis de ruído e o georreferenciamento. Isso cumpre, por exemplo, a importante função descritiva dos aspectos físicos dos lugares a serem investigados.

No quadro a seguir (Figura 2), sumariamos os elementos temáticos que constituiriam nosso modelo de programa de pesquisa multidimensional (PPmD). A coluna da esquerda compreende tópicos pertinentes a cada uma das três dimensões descritas antes (física [F], fisiológica ou orgânica [O] e cultural [C]). Enquanto a coluna da direita expõe procedimentos metodológicos em versão híbrida, posto que, recuperando os elementos antecedentes, especializados, passam já a incorporar os níveis de abordagem espacial e sistêmico.

\section{DIMENSÕES PARCIAIS}

[F]

energia informativa (pressure waves)

[O]

percepção organísmica (acoustic behavior)

[C]

interpretação e reação ao som (cultural heritage)

\section{ENQUADRAMENTO ESPACIAL}

ECOLOGIA DA PAISAGEM SONORA

ex: Medições em "Psicoacústica" noise exposure ; loudness , tonality...

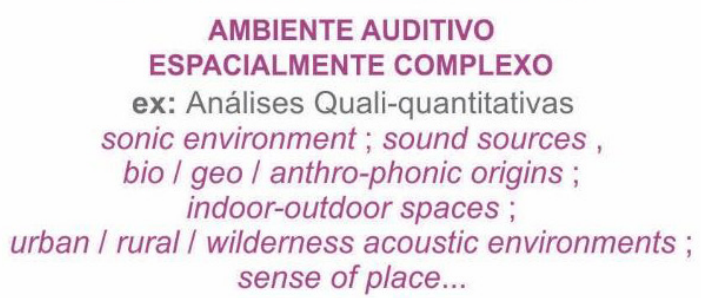

Figura 2. Plano temático do PPmD. Fontes: Farina (2014) e Kang e Schulte-Fortkamp (2016). 


\title{
Considerações finais: uma geografia da música a partir de uma geografia dos ruídos
}

Para Schoenberg (2001:46):

\begin{abstract}
Um autêntico sistema deve, antes de tudo, possuir fundamentos que abarquem todos os acontecimentos; melhor dizendo, tantos acontecimentos quantos realmente existem, nem um a mais ou a menos. Tais princípios são as leis naturais. Somente princípios que não necessitam de exceções teriam o direito de ser considerados válidos sempre. Fundamentos estes que compartilham com as leis naturais a característica da validade incondicional. Mas as leis artísticas compõem-se, sobretudo, de exceções.
\end{abstract}

Aplicando tal linha de raciocínio, nossos três conceitos -som, ruído e paisagem sonora- se apresentam como propícios a favorecer uma abordagem relevante em geografia da música e, particularmente, em geografia dos ruídos pois, como Schafer (2011a:23) defende: "o ambiente acústico de uma sociedade pode ser lido como um indicador das condições sociais que o produzem e nos contar muita coisa a respeito das tendências e da evolução dessa sociedade”. Partindo do pressuposto de que som é um fenômeno fundamentalmente natural, mas que a humanidade foi, no transcurso de sua história, introduzindo uma série de sons artificiais (a partir não apenas de artefatos que, sofisticados, viriam a se constituir em instrumentos de execução sonora, mas também de equipamentos industriais, veículos etc.), Schafer (2011a) categoriza os sons como "não esquizofônicos" -aqueles cuja origem é a natureza- e como "esquizofônicos" -aqueles cuja origem é intermediada por algum tipo de intervenção humana-. Tais considerações nos abrem caminho para investigar a relação geográfica entre paisagem sonora e lugar.

Schafer (2011a) aponta também que os sons da natureza exercem influência na psique humana. Esta concepção de interferência intrínseca dos sons naturais como delineadora" do caráter humano -enquanto elementos que criam códigos capazes de comunicar determinados eventos e identidades ou de representar especificidades locais que criam elos de afetividade de uma coletividade com o lugar- vai ao encontro da teorização de Tuan (1980). Porque em sua geografia da percepção, o conceito de topofilia define o processo perceptivo como "a resposta dos sentidos aos estímulos externos, como a atividade proposital, na qual certos fenômenos são claramente registrados (...)” (Tuan, 1980:4).

É possível inferir também que alguns desses "sons naturais", ou fundamentais, foram as primeiras referências sonoras com as quais os seres humanos começaram a desenvolver musicalidade. Estudos em antropologia e arqueologia sugerem que é da tentativa de reproduzir os sons da natureza -por exemplo, nos rituais em que, possivelmente, se desejava estabelecer certa conexão com divindades- que nasce a música. Por suposto, é lícito afirmarmos que toda expressão musical produzida pela espécie humana tem como referência um conjunto de sonoridades que, naturalmente, tende a ser familiar ao sujeito produtor de música. Isso porque é a partir da percepção que este sujeito tem da(s) paisagem(ns) sonora(s) que lhe cerca(m) que ele acumulará um arcabouço de sons que aparecerão reproduzidos no fazer musical. Tanto Schafer (2011a), quanto a antropologia do ruído de Wisnik (1989), dão lastro teórico para este ponto. 
Onde o físico encontra o humano: proposição...

Nina Puglia Oliveira, Dante Flávio da Costa ReIs JúNioR

Ainda Wisnik (1989:27-28) explica que "o som tem um poder mediador, hermético: é o elo comunicante do mundo material com o mundo espiritual e invisível”, completando que "ao fazer música, as culturas trabalharão nesta faixa em que som e ruído se opõem e se misturam. Descreve-se a música originariamente como a própria extração do som ordenado e periódico do meio turbulento dos ruídos". Assim sendo, a origem da música, segundo o autor, está relacionada a um anseio humano de invocar o cosmos na tentativa de ordenar o caos. Neste contexto, as escalas musicais seriam sistemas desenvolvidos para administrar a relação entre som e ruído, definindo o "caráter estável ou instável dos materiais sonoros” (Wisnik, 1989:30). O autor sustenta, portanto, que a história da música ocidental está intrinsecamente ligada à tentativa humana de ordenar o caos através de um fazer musical no qual o principal paradigma é a exclusão do ruído e de qualquer combinação sonora considerada dissonante; e que esta teoria musical chegaria a um "modelo utópico da sociedade harmonizada e/ou, ao mesmo tempo, a mais bem acabada representação ideológica (simulação interessada) de que ela não tem conflitos" (Wisnik, 1989:34).

Wisnik (1989) e Schafer (2011a) apontam a harmonia das esferas de Pitágoras como a mais antiga e sólida sistematização de sons para a finalidade musical no mundo ocidental. É da série harmônica que parte toda a elaboração do sistema tonal, a teoria musical que vai reger a música ocidental, sobretudo a partir do período Barroco, alcançando sua culminância máxima no Romantismo europeu, quando se saturam todas as possibilidades harmônicas que o sistema tonal oferecia. A consequência, como já mencionado, é a ruptura deste sistema pela geração de compositores como Arnold Schoenberg, que propôs uma verdadeira e profunda revisão dos dogmas da teoria musical tonal. Schoenberg amplia o entendimento sobre música enquanto linguagem artística ao propor a supracitada análise sistêmica do fazer musical.

O olhar geográfico aqui proposto pretende justamente contribuir para esta análise. Propor uma Geografia da Música a partir de uma Geografia dos Ruídos é conceder à investigação este olhar sistêmico e multidimensional. Compreender o processo de produção de música em sua magnitude deve, ao que parece, incluir uma análise sobre a influência do ruído na paisagem sonora pois, dependendo das características espaciais que formam uma paisagem sonora, o resultado é um maior ou menor grau de ruídos em determinados ambientes. Aqueles situados no espaço urbano tendem a ser mais ruidosos em relação aos situados em zonas rurais, por exemplo. Essa é uma das constatações que Schafer (2011a) fez nas pesquisas do seu Projeto Acústico e é também uma tese defendida por Torres e Kozel (2010).

Foi observado por Schafer (2011a) que, particularmente, a Revolução Industrial teve uma influência decisiva na transformação das paisagens sonoras europeias, ao inserir uma série de sonoridades que antes não existiam. Sonoridades produzidas por equipamentos, maquinários e toda uma sorte de artefatos tecnológicos. A esse novo emaranhado de sons esquizofônicos já não mais identificáveis Schafer (2011a:107) denominou "paisagem sonora lo-fi". A partir daí, ele aponta que a humanidade entrou em uma linha contínua de ruídos, até o ponto da total esquizofonia, definida pelo autor como o "rompimento entre o som original e sua transmissão ou reprodução eletroacústica" (Schafer, 2011a:133). Logo, parece válido supor que estas novas sonoridades esquizofônicas, mescladas aos sons da natureza e a outras fontes sonoras não esquizofônicas, são também legítimas integrantes das paisagens sonoras contemporâneas. 
Onde o físico encontra o humano: proposição...

Nina Puglia Oliveira, Dante Flávio da Costa ReIs JúNioR

Poder-se-ia, então, incluir nas "questões coletivas sobre o espaço" levantadas por Roulier (1999) que a incidência de ruído engendra também a criação de música? Porque se a música é fruto de uma ação inerentemente humana, bem como essencialmente coletiva, trata-se de um questionamento pertinente que ainda precisaria ser melhor explorado pela ciência geográfica. Schafer (2011a:151) nos dá algumas pistas ao esclarecer que "a música forma o melhor registro permanente de sons do passado. Assim, ela será útil como guia para o estudo das modificações nos hábitos e nas percepções auditivas". O autor acrescenta, ainda, que existem duas espécies de música: "absoluta", na qual os compositores manipulam paisagens sonoras ideais para cada projeto musical; e a música "programática", que mimetiza o ambiente e é desvinculada do ambiente externo, como é caso da música de concerto, por exemplo.

Mas o que se sabe sobre a influência da percepção dos ruídos das paisagens sonoras na produção de música? Embora não tenha desenvolvido o tema de modo mais profundo, Roulier (1999) fornece indícios sobre como sua geografia dos ruídos poderia viabilizar a compreensão de uma geografia da música. Ao explicar que o interesse deste campo de estudo está em estabelecer "uma interpretação da sociedade pela sua produção de espaço sonoro" e nas "representações diferenciadas do espaço sonoro" (Roulier, 1999:6, tradução nossa) -salientando que tais representações devem ser entendidas em seus respectivos contextos, ou seja, em suas respectivas paisagens sonoras-, fica claro que a concepção deste autor se conecta suficientemente às linhas de pensamento dos demais autores aqui apresentados. E acrescenta que "a geografia do ruído pode ser abordada de duas maneiras: uma interpretação da sociedade pela sua produção de espaço sonoro (...); [e] representações diferenciadas do espaço sonoro (...)" (Roulier, 1999:7, tradução nossa).

Também exemplifica essa coordenação teórica a explicação de Wisnik (1989) sobre as duas vertentes musicais que surgiram no século XX, que se destacaram na cisão com as formas tradicionais de fazer música: o Serialismo, oriundo do dodecafonismo de Schoenberg, e o Minimalismo, que tem como principal representante o compositor estadunidense Philip Glass. Segundo o autor, respectivamente,

(...) uma teria seu correlato objetivo na experiência urbano-industrial da simultaneidade, da fragmentação e da montagem, técnicas de choque fundante da arte das vanguardas, e outra no caráter serial-repetitivo do mundo pós industrial informatizado, onde se engendra repetição da repetição em larga escala, com proliferação generalizada dos simulacros (Wisnik, 1989:175).

Estas mudanças de paradigma sobre a percepção da paisagem sonora e as propostas musicais vanguardistas abrem espaço para a análise de inúmeras outras vertentes musicais que proliferaram a partir da ruptura com a tonalidade e, posteriormente, a inclusão de aparelhos eletrônicos na produção musical. Particularmente, a música eletrônica aí nascida desencadeia toda uma nova gama de possibilidades que resultaram em novas identidades musicais, tanto eruditas como populares, que vão expressar a heterogeneidade ambiental em que se inserem as sociedades humanas contemporâneas.

A seguir (Figura 3), sintetizamos numa concepção gráfica a natureza compósita de nosso modelo de paisagem sonora. Sua análise recebe o aporte de três dimensões investigativas, cujas famílias de fenômenos estabelecem entre si uma lógica de complexidade 
Onde o físico encontra o humano: proposição...

Nina Puglia Oliveira, Dante Flávio da Costa ReIs JúNioR

progressiva. Nesse sentido, uma geografia da música (GM) pode ser tratada como uma emergência complexa a partir de uma geografia do ruído (GR), e que apenas vem à tona graças às existências precípuas do mundo físico (onde se encontram materiais e princípios de movimento, recursos naturais, dinâmicas de fluxo etc.) e do mundo vivo (sistemas biológicos cognitivamente qualificados).

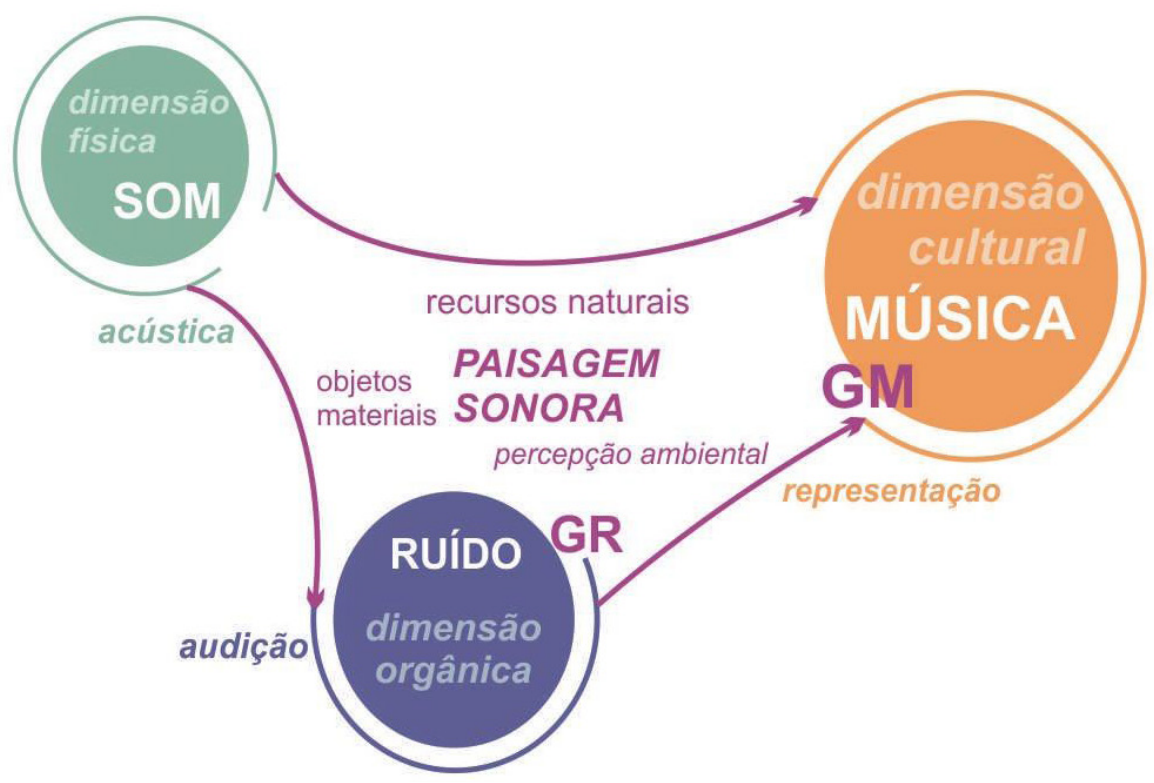

Figura 3. Modelo de constituição de uma geografia da música a partir do ruído. Fonte: elaboração própria.

Como se pode notar, há um portentoso manancial teórico que trata do som como insumo básico para a produção de música à espera de ser explorado pelos pesquisadores em Geografia. Apesar de inscritos em campos bastante heterogêneos entre si, esses conteúdos férteis são, eles próprios, de ordem interdisciplinar; fato que, em tese, já é um facilitador para que o pensamento geográfico deles se aproprie. Estudos etnográficos e de reconstituição histórica, empreendidos por antropólogos; estudos técnicos de fisiologia acústica desenvolvidos por especialistas que exploram a interface dos fenômenos biofísicos, etc. Um esforço de concertação entre esses aportes, sem dúvida, deteria a funcionalidade de robustecer toda argumentação, por exemplo, sobre a diversidade de povos no mundo, ressaltando que isso seria especialmente fecundo para as pesquisas geográficas interessadas em demonstrar o desenvolvimento de identidades musicais a partir de paisagens sonoras diferenciais (isto é, resultantes de ecossistemas, biomas, ecologias humanas e urbanas).

Embora todos os autores geógrafos aqui referenciados demonstrem admitir a interdisciplinaridade inerente às pesquisas em Geografia da Música, não consta nestes estudos uma significativa interface com as ciências naturais, algo que contribuiria ainda mais para a compreensão do fazer musical com ênfase na investigação do processo, ou seja, com ênfase propriamente no comportamento espacial. Por conta disso, entendemos que a multiplicação de pesquisas aplicadas, alinhadas com a perspectiva da multidimensionalidade, redundará num grande acervo de estudos acerca do comportamento espacial do som (e do ruído). Mas isso resultaria, é certo, precisando ter como base a 
Onde o físico encontra o humano: proposição...

Nina Puglia Oliveira, Dante Flávio da Costa Reis JúNIOR

relação entre a assimilação das paisagens sonoras e a construção de identidades musicais (presumivelmente singulares). Uma relação vivenciada, ao longo da história, pelas coletividades humanas em seus sistemas culturais; uma relação -às vezes de exclusão, indiferença ou incorporação- que cada uma delas estabeleceu com o ruído. 


\section{Q Bibliografia}

》Azevedo, A. F. (2018). Geografia e música: a Tocadora da Roda de Giacometti. Em A.F. de Azevedo, B.H. Furlanetto e M.B. Duarte (Orgs.), Geografias Culturais da Música (pp. 13-48). Braga: Universidade do Minho. Disponível em: http:// repositorium.sdum.uminho.pt/bitstream/1822/61302/3/GCM2018\%40LAB2PT.pdf

" Bader, R. (2013). Synchronization and self-organization as basis of musical performance, sound production, and perception. Em R. Bader (Ed.), Sound Perception - Performance. (pp. 3-41). Londres: Springer. Disponível em: https:// www.springer.com/gp/book/9783319001067

» Baldo, M.V., Haddad Junior, H. (2008). Realismo e instrumentalismo: possíveis contribuições de uma epistemologia biológica. V Encontro da Associação de Filosofia e História da Ciência do Cone Sul, Campinas, Brasil.

„ Cowan, J.P. (1994). Handbook of Environmental Acoustics. Nova York: J. Wiley.

" Cowan, J.P. (2016). The Effects of Sound on People. Chichester: J. Wiley.

" Crozat, D. (2016). Jogos e ambiguidades da construção musical das identidades espaciais. Em A. Dozena (Org.), Geografia e Música: diálogos (pp. 13-48). Natal: EDUFRN. Disponível em: https://repositorio.ufrn.br/jspui/ handle/123456789/21381

》Darwin, C.J. (2008). Spatial hearing and perceiving sources. Em W.A. Yost, A.N. Popper e R.R. Fay (Eds.), Auditory Perception of Sound Sources (pp. 215-232). Nova York: Springer.

» Farina, A. (2014). Soundscape Ecology: principles, patterns, methods and applications. Dordrecht: Springer.

» Fletcher, N.H. (2007). Animal bioacoustics. Em T. Rossing (Ed.). Springer Handbook of Acoustics (pp. 785-802). Nova York: Springer.

" Golledge, R. G. (2006). Philosophical bases of behavioral research in geography. Em S. Aitken and G. Valentine (Eds.), Approaches to Human Geography (pp. 7585). Londres: Sage.

» Hoffmann, R. e Löbe, L.P. (2019). Ernst Mach and Johannes Kessel in Prague 1871-1874. Em F. Stadler (Ed.), Ernst Mach: life, work, influence (pp. 245-257). Cham: Springer.

» Kang, J. e Schulte-Fortkamp, B. (Eds.) (2016). Soundscape and the Built Environment. Boca Raton: CRC.

» Kong, L. (1995). Popular music in geographical analysis. Progress in Human Geography, 19(2), 183-198.

》 Kursell, J. (2013). Experiments on tone color in music and acoustics: Helmholtz, Schoenberg, and Klangfarbenmelodie. Osiris, 28(1), 191-211.

» Lefebvre, J.P. (1999). Physical basis of acoustics. Em P. Filippi, D. Habault, J.P. Lefebvre e A. Bergassoli (Eds.), Acoustics: basic physics, theory, and methods (pp. 1-39). Londres: Academic Press. 
Onde o físico encontra o humano: proposição...

Nina Puglia Oliveira, Dante Flávio da Costa ReIs JúNioR

»Leyshon, A., Matless, D. e Revill, G. (Eds.). (1998). The Place of Music. Nova York: The Guilford Press.

" Matthen, M. (2015). Active perception and the representation of space. Em D. Stokes, M. Matthen e S. Biggs (Eds.). Perception and its Modalities (pp. 44-72). Nova York: Oxford University Press.

》 Merriam, A. P. (1980). The Anthropology of Music. Evanston: Northwestern University Press.

" McAdams, S. (2019). The perceptual representation of timbre. Em K. Siedenburg, C. Saitis, S. McAdams, A. N. Popper e R. R. Fay (Eds.), Timbre: acoustics, perception, and cognition. (pp. 23-57). Cham: Springer.

» Moore, B.C. (2007). Psychoacoustics. Em T. Rossing (Ed.), Springer Handbook of Acoustics (pp. 459-501). Nova York: Springer.

" Morley, I. (2013). The Prehistory of Music: human evolution, archaeology, and the origins of musicality. Oxford, UK: Oxford University Press.

"Nash, P. e Carney, G. (1996). The seven themes of music geography. The Canadian Geographer, 40(1), 69-74.

» Oliveira, N.P. (2014) Análise socioespacial do mercado de música em Brasília - DF. Dissertação de Mestrado em Geografia, Universidade de Brasília. Disponível em: https://repositorio.unb.br/handle/10482/16210

"Paiva, D. (2018). Sonic geographies: themes, concepts, and deaf spots. Geography Compass, 12(7), 1-14. Disponível em: https://www.onlinelibrary.wiley.com/doi/ abs $/ 10.1111 /$ gec 3.12375

»Panitz, L.M. (2010). Por uma geografia da música. 0 espaço geográfico da música popular platina, Dissertação de Mestrado em Geografia, Universidade Federal do Rio Grande do Sul. Disponível em: https://www.lume.ufrgs.br/bitstream/ handle/10183/27035/000762181.pdf

»Panitz, L.M. (2019). Redes musicais e (re)composições territoriais no Prata: por uma geografia da música. Espaço e Cultura, Rio de Janeiro, 45, 11-30. Disponível em: https://www.e-publicacoes.uerj.br/index.php/espacoecultura/article/ view/48531

»Pickles, J. O. (2012). An Introduction to the Physiology of Hearing (4a ed.). Bingley, UK: Emerald.

»Pocock, D. (1989). Sound and the geographer. Geography, 74(3), 193-200. Disponível em: http://www.jstor.org/stable/40571667

» Roulier, F. (1999). Pour une géographie des milieux sonores. Cybergeo: European Journal of Geography, 71. Disponível em: https://journals.openedition.org/ cybergeo/5034

》Santos, M. (2008). A Natureza do Espaço: técnica e tempo, razão e emoção. São Paulo: EDUSP.

»Schafer, R.M. (2011a). A Afinação do Mundo (2a ed.). São Paulo: UNESP.

»Schafer, R.M. (2011b). O Ouvido Pensante (2a ed.). São Paulo: UNESP.

"Schoenberg, A. (2001 [1911]). Harmonia. São Paulo: UNESP.

"Seikel, J.A., King, D.W. e Drumright, D.G. (2010). Anatomy \& Physiology: for speech, language, and hearing (4a ed.). Clifton Park: Cengage Learning. 
Onde o físico encontra o humano: proposição...

Nina Puglia Oliveira, Dante Flávio da Costa ReIs JúNioR

"Siedenburg, K., Saitis, C. e McAdams, S. (2019). The present, past, and future of timbre research. Em K. Siedenburg, C. Saitis, S. McAdams, A.N. Popper e R.R. Fay (Eds.), Timbre: acoustics, perception, and cognition (pp. 1-19). Cham: Springer.

»Soler, L. (2009). Introduction à l'Épistémologie. Paris: Ellipses.

» Torres, M. A. e Kozel, S. (2010). Paisagens sonoras: possíveis caminhos para a geografia. Revista RA'E GA, 20, 123-132. Disponível em: https://revistas.ufpr.br/ raega/article/view/20616/13762

» Torres, M. A. e Kozel, S. (2012). A paisagem sonora da llha dos Valadares: percepção e memória na construção do espaço. Em F. Barthe-Deloizy e A. Serpa (Orgs.), Visões do Brasil: estudos culturais em geografia (pp. 167-190). Salvador: EDUFBA. Disponível em: http://books.scielo.org/id/8pk8p/pdf/ barthe-9788523212384-10.pdf

» Tuan, Y.F. (1980). Topofilia: um estudo da percepção, atitudes e valores do meio ambiente. São Paulo: DIFEL.

» Turvey, M.T. (2019). Lectures on Perception: an ecological perspective. Nova York: Routledge.

"Veal, D. (2005). Continental philosophy and the sciences: the German tradition. ANGELAKI: Journal of the Theoretical Humanities, 10(1), 1-31.

»Vogel, S. (1993). Sensation of tone, perception of sound, and empiricism: Helmholtz's physiological acoustics. Em D. Cahan (Ed.). Hermann von Helmholtz and the Foundations of Nineteenth-Century Science (pp. 269-287). Berkeley: University of California Press.

»Wisnik, J.M. (1989). O Som e o Sentido: uma outra história das músicas. São Paulo: Companhia das Letras.

\section{Nina Puglia Oliveira / ninapuglia@gmail.com}

Doutoranda em Geografia pela Universidade de Brasília e técnica em Música pela Escola de Música de Brasília. Atua como pesquisadora de Geografia da Música, como professora de Geografia e de Música na rede privada de ensino, e como produtora cultural em diversos projetos.

Dante Flávio da Costa Reis Junior / dantereis@unb.br

Doutor em Ciências pela Universidade Estadual de Campinas. Pesquisador nas áreas de história, filosofia e ensino de ciências, e comunicação científica. Professor Associado 2 junto ao Departamento de Geografia da Universidade de Brasília. 